\title{
PUMICE STONE ENGINEERING AND RICE HUSK ASH LIGHT AGGREGATE MATERIAL TO INCREASE THE COMPRESSIVE STRENGTH OF COMPOSITE LIGHTWEIGHT CONCRETE
}

\author{
Moh Azhar \\ Department of Civil Engineering, University of Tama Jagakarsa, Jakarta, Indonesia
}

Atjep Soedarjanto

Department of Civil Engineering, Institute Sciences and Technology National,

Jakarta, Indonesia

\section{Anugraha Syah}

Department of Civil Engineering, Institute Sciences and Technology National, Jakarta, Indonesia

\begin{abstract}
Research has been carried out on the manufacture of lightweight concrete (LWC) using lightweight aggregate (LWA) material of pumice and rice husk ash. The lightweight concrete sample made is with a variety of different slump values, while the portland cement composite (PCC), sand, pumice and rice husk ash (RHA) materials are kept constant. There are two main parameters that determine the mechanical properties of lightweight concrete, each of which is the sample density and water I cement ratio. Observation of photomicro SEM pumice shows that there are many pores with a shape extending to the inside of the surface of the concrete sample. Pores come with relatively large pore density and varying sizes. This fact explains why pumice is light because it has a low mass density. As seen in Photomicro SEM lightweight concrete, the Calcium Silicate Hydrate (CSH) compound starts to grow at the beginning of the hydration process and continues to grow until lightweight concrete reaches 28 days of hydration which is characterized by solid physical properties and increased compressive strength of lightweight concrete. It can be ascertained that the Calcium Silicate Hydrate compound has an important role in regulating mechanical properties such as compressive strength. In the mixture with the variation of the largest slump value $(13 \mathrm{~cm})$ produces the lowest density and compressive strength of $1755.7 \mathrm{~kg} / \mathrm{m}^{3}$ and $20.0 \mathrm{MPa}$, respectively. X-ray diffraction patterns of lightweight concrete samples show the dominance of the crystalline phase identified as quartz ( $\left.\mathrm{SiO}_{2}\right)$ phase. However, it can be ascertained that lightweight
\end{abstract}


Pumice Stone Engineering and Rice Husk Ash Light Aggregate Material to Increase the Compressive Strength of Composite Lightweight Concrete

concrete samples consist of a mixed phase between crystalline phases and a little amorph phase. This study concludes that pumice and rice husk ash are silica amorph based materials that have lower density, especially compared to other concrete forming materials such as cement. Both the density and compressive strength of lightweight concrete samples are determined by the ratio between pumice and rice husk ash. The smallest ratio of pumice stone compared to rice husk ash was 8.1 with 9 $\mathrm{cm}$ slump value resulting in optimum density and compressive strength values, respectively at 28 days of lightweight concrete with $1794.7 \mathrm{~kg} / \mathrm{m}^{3}$ and $23.7 \mathrm{MPa}$. The best lightweight concrete composition obtained from the results of this study is that with a $9 \mathrm{~cm}$ slump value is indicated by the ratio between the compressive strength and the highest density of 1321.

Keywords: Pumice, Rice Husk Ash, Lightweight Concrete, Density, and Compressive Strength

Cite this Article: Moh Azhar, Atjep Soedarjanto and Anugraha Syah, Pumice Stone Engineering and Rice Husk Ash Light Aggregate Material to Increase the Compressive Strength of Composite Lightweight Concrete, International Journal of Civil Engineering and Technology, 11(8), 2020, pp. 50-57.

https://iaeme.com/Home/issue/IJCIET?Volume $=11 \&$ Issue $=8$

\section{INTRODUCTION}

Concrete is a composite material obtained from a process of mixing several materials, and hardened water as time develops into solid objects. Concrete composition consists of cement, fine aggregate, coarse aggregate, water and air cavity. The air cavity has an influence on the compressive strength of the concrete. The greater the volume of air cavity contained in the concrete, the compressive strength of the concrete will decrease and conversely the smaller the volume of air cavity contained in the concrete, the compressive strength of the concrete will increase. The process of making concrete is formed from cement and water which produces cement paste which is used to bind coarse aggregates and fine aggregates. The mixture of concrete formation materials is determined in such a way that it produces fresh concrete that is easy to work on and meets the compressive strength of the plan after hardening and is quite economical. Until the last decade, concrete has become one of the most important choice materials for use in building construction.

Besides the use of conventional concrete that has been commonly used in building construction, there are other alternatives as conventional concrete substitutes, namely using lightweight aggregate (LWA), in terms of more economical costs and in terms of lighter loading, lightweight concrete (LWC) is also called lightweight aggregate concrete or is heavy concrete type smaller than concrete in general, namely concrete that has a dry mass of air in accordance with the conditions in "Testing Method for Units of Weight of Structural Lightweight Concrete" ASTM C567-91 (1996), where the specific gravity is not more than $1900 \mathrm{~kg} / \mathrm{m}^{3}$. Lightweight concrete can be made in various ways, including by: using lightweight aggregates. Unlike normal concrete, the weight of lightweight concrete can be adjusted as needed. In general, the weight of lightweight concrete ranges from $1600-1900 \mathrm{~kg}$ $/ \mathrm{m}^{3}$. Because of this the advantages of lightweight concrete are mainly in weight, so that when used in high-rise building projects it can significantly reduce the weight of the building itself, which in turn affects the calculation of the foundation.

Cement acts as a binder when reacting with water to form a dominant structure consisting of Calcium Silicate Hydrates ( $\mathrm{CSH}$ ), which grow to form a plate-shaped structure as a product of hydration. In the early stages of the hydration process, the structure is still not so dense, 
which is characterized by the presence of pores or cavities. The hydration mechanism can be analyzed through the growth of micro-paste cement structures at different times during the hydration process. Porosity decreases with increasing hydration time, this is due to the growth of Calcium Silicate Hydrate crystallite as hydration increases. Microstructure evolution of Calcium Silicate Hydrate in cement paste on day 7, 28 and 56 for 100\% Portland cement characterized by SEM showed that the structure of Calcium Silicate Hydrate began to expand or grow early and continued to develop until the structure was denser than Calcium Silicate Hydrates present at the end of time (56 days). Solid structures make concrete more durable because it is resistant to environmental attacks. (A. Manaf, and V. Indrawati, 2011).

The results of SEM micrographs from rice husk ash samples showed very porous surface morphology, with high surface area. This seems enough for certain applications such as special ceramic materials, catalyst support or building materials. Phase identification in rice husk ash was obtained by XRD. The pattern is in the form of very broad lines and no peaks, defined by crystallinity. It also represents the theoretical position of the main mind in the cristobalite $\left(\mathrm{SiO}_{2}\right)$ and graphite $(\mathrm{C})$ phases and no peaks are found in this position. The results obtained concluded that the ash produced had an amorph structure (Rosario Madrid, et al., 2012).

Half open porous structures of pumice aggregates are mostly influenced by the increase in compressive strength by increasing the quality of epoxy as a binder with aggregate, seen on the surface there are pores of various shapes and sizes with a considerable amount of density, this shows the low density of pumice. On the other hand, because of the half-open pumice surface structure, portland cement requires more material as epoxy resin compared to portland cement with normal aggregate (Tayfun Uygunoglu, et al, 2013).

The weakest component of lightweight concrete does not lie in cement as its matrix or interface transition zone but lies in its aggregate. Hence, the mechanical performance of lightweight concrete is not only controlled by the quality of cement as a matrix but also by the aggregate volume in the concrete and the aggregate properties (Chi et al, 2003). Various researches have been carried out regarding the study of the behavior of lightweight concrete, so Zhang and Gjorv show the effect of density on lightweight concrete on mechanical strength and failure mechanisms on high-performance lightweight concrete (Zhang and Gjorv, 1991). Yang and Huang highlight the importance of the volume fraction of lightweight concrete to the compressive strength and elastic modulus of lightweight concrete (Yang and Huang, 1998). Generally, the quality of lightweight concrete is not only seen from its density but also from its mechanical properties. Wasserman and Bentur conducted research that the same aggregate density did not produce the same strength of concrete (Wasserman and Bentur, 1997).

\section{RESEARCH METHODS}

The process of making composite portland cement paste was started by preparing variations in material composition consisting of cement, fine aggregate, water, rice husk ash, and pumice as coarse aggregate. Rice husk ash comes from the residual process of burning brick fuel that passes filter no.200. While the pumice is processed with a stone breaking machine into coarse aggregate. Then an examination of coarse and fine aggregates is carried out to determine the characteristics of each aggregate. After that, a mixed design calculation is done based on the research plan.

The standards used in physical testing of lightweight concrete materials are taken from ASTM standards. While the mixed design calculation method used is the calculation of concrete mix based on the weight ratio and aggregate use in a saturated surface dry (SSD). 
The mixed plan carried out in this study was a fixed variation of pumice and a different Slump value of 4 variations, while the proportion of mixture of cement (PCC), sand, pumice, rice husk ash (RHA), and water to cement ratio (w/c) as in Table 1. following:

Table 1 Proportion of mixtures of cement, sand, pumice, rice husk ash, and w/c

\begin{tabular}{|c|c|c|c|c|c|}
\hline Cube & PCC & Sand & Pumice & RHA & w/c \\
\hline 1 & 1.00 & 1.00 & 0.45 & 0.05 & 0.43 \\
\hline 2 & 1.00 & 1.00 & 0.45 & 0.05 & 0.47 \\
\hline 3 & 1.00 & 1.00 & 0.45 & 0.05 & 0.51 \\
\hline 4 & 1.00 & 1.00 & 0.45 & 0.05 & 0.55 \\
\hline
\end{tabular}

Workability testing is done in fresh concrete dough to get the slump value, after that a concrete cube with a size of $15 \times 15 \times 15 \mathrm{~cm}$ is made, after 24 hours the concrete cube is opened from the mold, then the cube is immersed in water and a compressive Strength Test, Density test, is carried out. SEM test, and XRD test at the age of 7, 14, and 28 days.

\section{RESULTS AND DISCUSSION}

\subsection{Lightweight Concrete Compressive Strength}

After knowing each specification of fine aggregate, rice husk ash, and coarse aggregate of pumice, compressive strength test was then performed as the main parameter to determine the quality of lightweight concrete made. From the results of the experimental data analysis and calculation of the density and compressive strength of the concrete were carried out, as shown in Table 2

Table 2 Slump Value, Density, and Compressive Strength of Lightweight Concrete aged 7. 14. 28 days

\begin{tabular}{|c|c|c|c|c|}
\hline Cube & $\begin{array}{l}\text { Time } \\
\text { (Day) }\end{array}$ & $\begin{array}{c}\text { Slump } \\
(\mathbf{c m})\end{array}$ & $\begin{array}{l}\text { Density } \\
\left(\mathrm{kg} / \mathrm{m}^{3}\right)\end{array}$ & $\begin{array}{c}\text { Compressive } \\
\text { Strength } \\
\text { (MPa) }\end{array}$ \\
\hline \multirow{3}{*}{1} & 7 & \multirow{3}{*}{7} & 1726.5 & 18.1 \\
\hline & 14 & & 1739.9 & 19.7 \\
\hline & 28 & & 1774.7 & 21.4 \\
\hline \multirow{3}{*}{2} & 7 & \multirow{3}{*}{9} & 1736.5 & 19.4 \\
\hline & 14 & & 1759.8 & 20.7 \\
\hline & 28 & & 1794.7 & 23.7 \\
\hline \multirow{3}{*}{3} & 7 & \multirow{3}{*}{11} & 1733.1 & 18.9 \\
\hline & 14 & & 1748.2 & 20.1 \\
\hline & 28 & & 1779.7 & 22.6 \\
\hline \multirow{3}{*}{4} & 7 & \multirow{3}{*}{13} & 1716.3 & 16.9 \\
\hline & 14 & & 1728.2 & 17.7 \\
\hline & 28 & & 1755.7 & 20.0 \\
\hline
\end{tabular}

The presence of pumice and hydration processes that have not been optimal will leave the pores open and the pores closed. Both pumice and rice husk ash both have a relatively low mass density compared to the mass density of other materials which make up concrete such as cement and sand. Quantitatively, the use of pumice with a large fraction, will have a large pore fraction value, therefore the actual sample density will tend to be low.

A comparison chart of the concrete compressive strength of the four samples was made at the age of 7 to 28 days as shown in Figure 1. Also made a graph between the Slump value and the concrete compressive strength as shown in Table 3. 


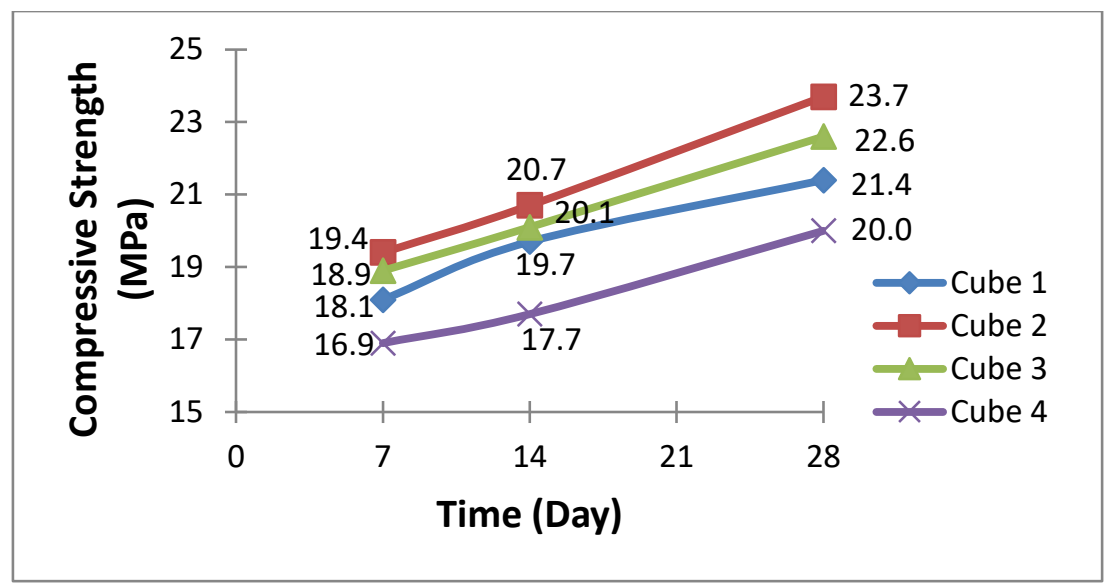

Figure 1 Graph Concrete compressive strength at the age of 7,14 and 28 days in the process of hardening cube concrete $1-4$

Table 3 Ratio between compressive strength to sample density 1-4 age 28 days

\begin{tabular}{|c|c|c|c|c|}
\hline Cube & 1 & 2 & 3 & 4 \\
\hline$\sigma / \rho$ & 1206 & 1321 & 1270 & 1139 \\
\hline
\end{tabular}

For more details, Table 3 is made a comparison graph between the ratio of compressive strength and density at 28 days of concrete as shown in Figure 2 below.

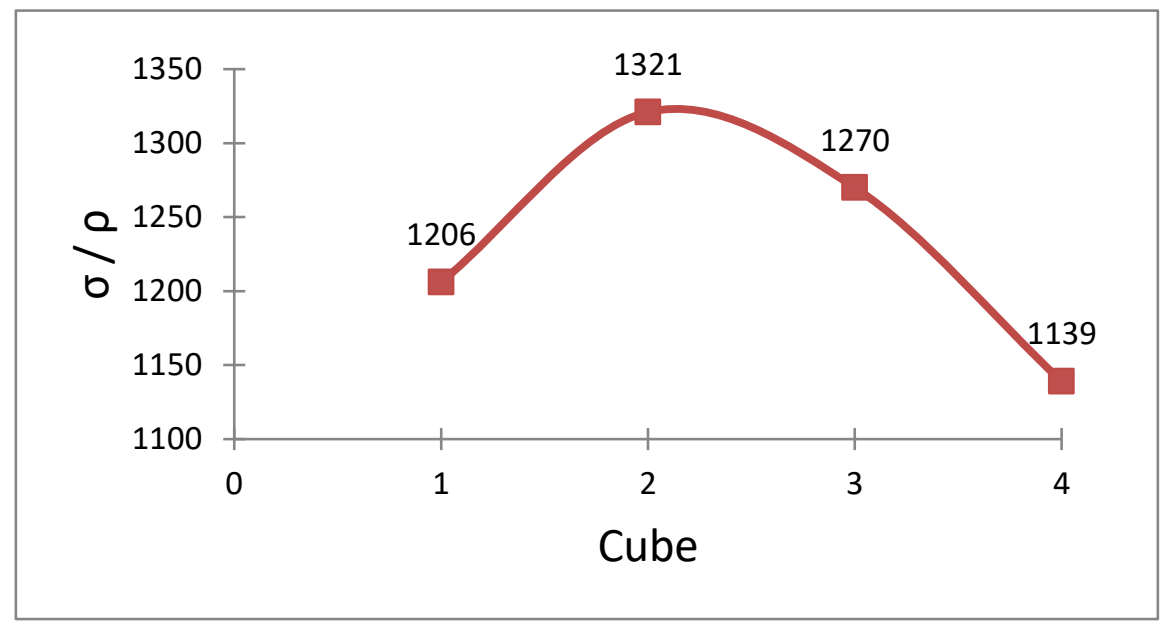

Figure 2. Comparison of concrete compressive strength to Density at 1- 4 age cubes 28 days

Figure 2 shows that the sample cube 4 has a compressive strength ratio to the smallest density of 1139, while the largest price is obtained in the sample cube 2 with a value of 1321 . Thus it can be said that of the 4 samples of lightweight concrete cube the results of this study were taken the largest is obtained in the cube sample 2.

From the series of results of the analysis of the mechanical strength of the lightweight concrete above, it can be understood that the mechanism of lightweight concrete reinforcement is if there is an increase in the compressive strength of the concrete will always be followed by an increase in the density value, but this is not always followed by the slump value. 
Sample surface microstructure lightweight concrete in the form of SEM photos was shown to visually see the morphology of the compounds formed. In Figure 3.3, the results of SEM of Lightweight Concrete Age 7, 14, and 28 days with magnification $10000 \mathrm{x}$

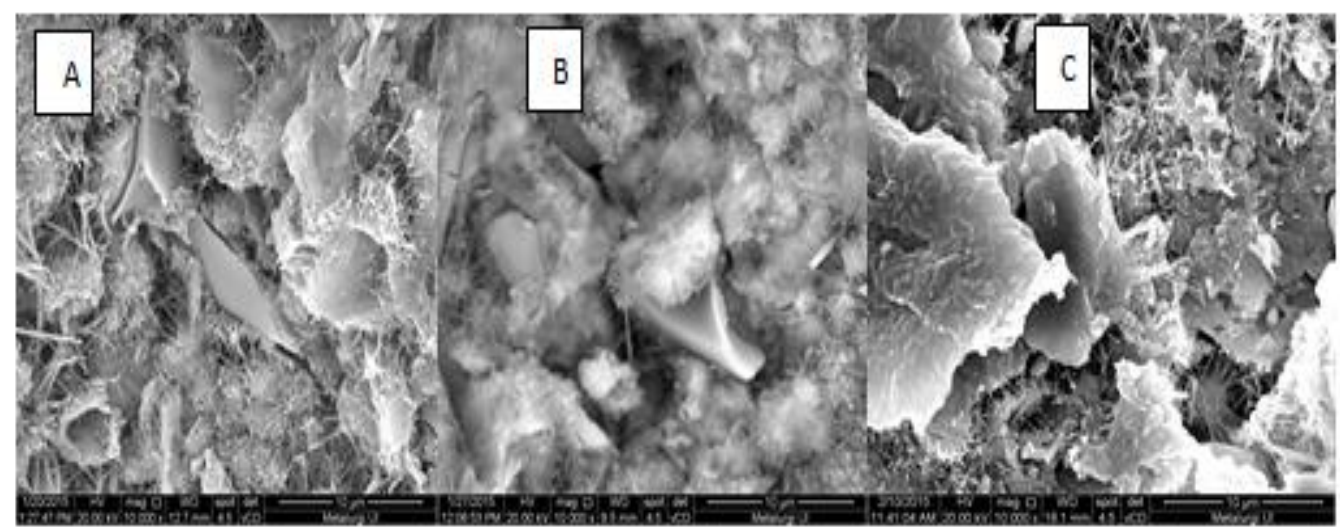

Figure 3 SEM images of 7 days (A), 14 days (B) and 28 days (C), magnification $10000 \mathrm{x}$

In Figure 3 SEM photo shows that some possibilities occur on the surface of composite material, where some cement fills cavities in pumice during a cement hydration process, this causes reinforcement during the process as time goes on. There is a correlation between the speed of hydration and heat of hydration, initially the hydration reaction of cement is fast enough but then slower. Correspondingly, the power develops quickly at first, then as time goes by, the speed of increase in strength decreases. This increase in strength occurs continuously for a long time.

The results of SEM photos show that the CSH structure begins to expand or grow at an early time and continues to develop until the structure is denser at 28 days. CSH is the main product of the hydration process in portland composite cement, where the compound is fully responsible and has an important role in regulating mechanical and physical properties such as compressive strength after hardened cement paste.

Figure 4 is a lightweight concrete diffraction photo. The diffraction pattern has been dominated by crystalline phase, some diffraction peaks are clear and sharp, the highest predicted peak is the quartz $\left(\mathrm{SiO}_{2}\right)$ phase, while the lower possible peaks are the Andesine, Portlandite, Calcite and C4AF phases. Hence, it is estimated that lightweight concrete is a mixture of crystalline phases and there is little amorph phase.

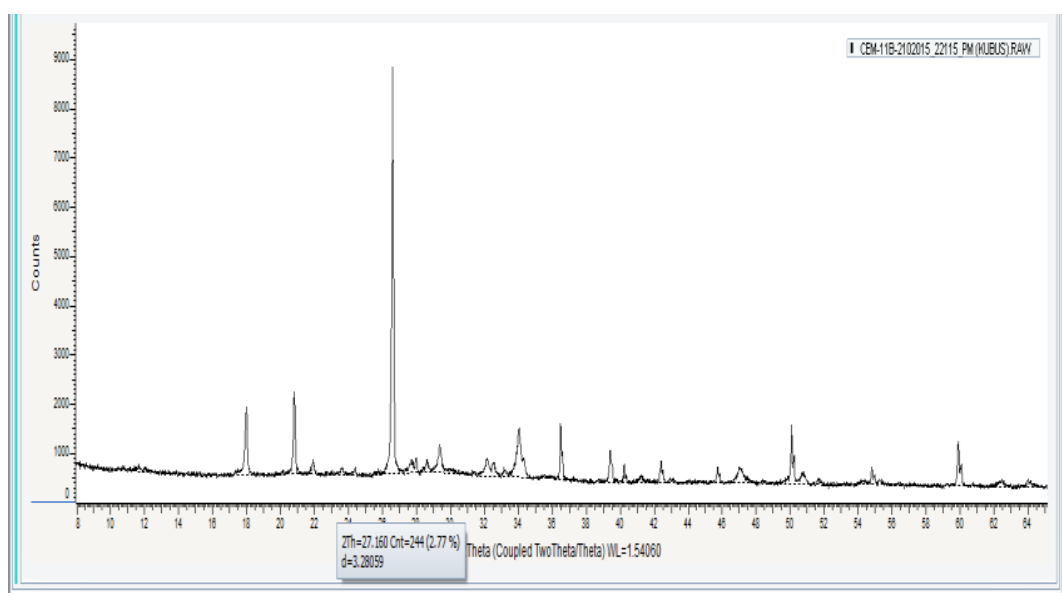

Figure 4 XRD pattern of 28-day lightweight concrete diffraction patterns 
In Table 4, Table 5, and Table 6 summarized the results of quantitative XRD tests on lightweight concrete at various ages, pumice, and rice husk ash. This test includes the identification of the phases in the sample and the evaluation of the phase fraction, namely changes in composition.

Table 4 Lightweight Concrete mineralogy results aged 7, 14, 28 days

\begin{tabular}{|c|l|c|c|c|}
\hline \multirow{2}{*}{ No } & \multirow{2}{*}{ Mineral } & \multicolumn{3}{|c|}{ Ages (days) / Value (\%) } \\
\cline { 3 - 5 } & & $\mathbf{7}$ & $\mathbf{1 4}$ & $\mathbf{2 8}$ \\
\hline 1 & Amorphous & 4.80 & 6.50 & 10.83 \\
\hline 2 & C4AF & 4.38 & 3.98 & 6.65 \\
\hline 3 & Portlandite & 7.15 & 9.74 & 13.80 \\
\hline 4 & Quartz & 60.07 & 54.52 & 39.69 \\
\hline 5 & Langbeinite & 2.27 & 2.18 & 2.35 \\
\hline 6 & Gypsum & 3.14 & 3.02 & 2.10 \\
\hline 7 & Calcite & 5.24 & 5.72 & 7.23 \\
\hline 8 & Andesine & 8.47 & 9.70 & 12.86 \\
\hline 9 & Total & 99.99 & 100.01 & 100.01 \\
\hline 10 & Rwp & 6.79 & 6.82 & 7.53 \\
\hline 11 & GOF & 2.88 & 2.93 & 2.95 \\
\hline 12 & DW & 2.56 & 2.76 & 2.56 \\
\hline
\end{tabular}

Table 5 Pumice mineralogy test results

\begin{tabular}{|ll|c|}
\hline \multicolumn{2}{|c|}{ Mineral } & $\begin{array}{c}\text { Amounts } \\
(\%)\end{array}$ \\
\hline Amorphous & & 71.89 \\
\hline Quartz $\quad \mathrm{SiO}_{2}$ & 0.18 \\
\hline Andesine $\quad \mathrm{Na}_{0.5} \mathrm{Ca}_{0.5} \mathrm{Al}_{1.5} \mathrm{Si}_{2.5} \mathrm{O}_{8}$ & 2.12 \\
\hline Labradorite & $\mathrm{Na}_{0.35} \mathrm{Ca}_{0.65} \mathrm{Al}_{1.65} \mathrm{Si}_{2.35} \mathrm{O}_{8}$ & 18.14 \\
\hline Anorthite & $\mathrm{Ca} \mathrm{Al}_{2} \mathrm{Si}_{2} \mathrm{O}_{8}$ & 6.56 \\
\hline Calcite & $\mathrm{CaCO}_{3}$ & 1.11 \\
\hline Total & & 100.00 \\
\hline Rwp & 3.94 \\
\hline GOF & 1.48 \\
\hline DW & 1.04 \\
\hline
\end{tabular}

Table 6 Mineralogy of rice husk ash

\begin{tabular}{|ll|c|}
\hline & Mineral & Amount (\%) \\
\hline Amorphous & & 53.65 \\
\hline Quartz & $\mathrm{SiO}_{2}$ & 6.65 \\
\hline Hematite & $\mathrm{Fe}_{2} \mathrm{O}_{3}$ & 3.74 \\
\hline Labradorite & $\mathrm{Na}_{0.35} \mathrm{Ca}_{0.65} \mathrm{Al}_{1.65} \mathrm{Si}_{2.35} \mathrm{O}_{8}$ & 5.53 \\
\hline Calcite & $\mathrm{CaCO}_{3}$ & 8.68 \\
\hline Magnesite & $\mathrm{MgCO}_{3}$ & 4.16 \\
\hline Thermonarite & $\mathrm{Na}_{2} \mathrm{CO}_{3} \mathrm{H}_{2} \mathrm{O}$ & 7.87 \\
\hline Titanite & $\mathrm{CaTi}\left(\mathrm{SiO}_{4}\right) \mathrm{O}$ & 9.72 \\
\hline Total & & 100.00 \\
\hline
\end{tabular}

When noted Table 4 in the amorph phase only reaches between $4.80 \%-10.83 \%$ a drastic decrease compared to the amorph phase of lightweight concrete forming materials namely pumice $(71.89 \%)$ and rice husk ash $(53.65 \%)$ Of course this is related to the formation of crystalline phases during the hydration process, where crystalline phases are formed, 
Pumice Stone Engineering and Rice Husk Ash Light Aggregate Material to Increase the Compressive Strength of Composite Lightweight Concrete

especially silicate-based phases. When noted the data in Table 4, with time the material phases change. Hence, the hydration process for 7 to 28 days has caused changes in the composition of the lightweight concrete phase, especially the amorph and Andesine phases which experience an increase in the percentage volume of the phase fraction, while the quartz phase actually decreases in line with the increase in concrete hardening time.

\section{CONCLUSIONS}

From the results of this study some conclusions can be drawn as follows:

1. Both the density and compressive strength of lightweight concrete is determined by the ratio of pumice to rice husk ash, the smallest ratio is 8.1 with a slump value of 9 resulting in optimal density and compressive strength values, respectively at 28 days of concrete at 1794.7 $\mathrm{kg} / \mathrm{m} 3$ and $23.7 \mathrm{MPa}$.

2. Pumice and rice husk ash which is part of the lightweight concrete forming material is a silica amorph based material which has a lower density compared to other concrete forming materials such as cement and sand.

\section{REFERENCES}

[1] A. Manaf, and V. Indrawati, Portland-Blended Cement with Reduced CO2 using Trass Pozzolan, Journal of the Korean Chemical Society, 2011, Vol. 55, No. 3. Printed in the Republic of Korea. DOI 10.5012/jkcs.2011.55.3.000

[2] ASTM C567-91, (1996), Test Method for Unit Weight of Structural Lightweight Concrete, ASTM Standards: Concrete and Aggregates, V.04.02., Philadelphia

[3] Chi. J.M., Huang. R., Yang, C.C., Chang, J.J., Effect of aggregate properties on the strength and stiffness of lightweight concrete. Cem. Concr Compos 2003; 25(2): 197-205.

[4] Failla A, Mancuso P, Miraglia N, Ruisi V. Experimental-theoretical study on pumice aggregate lightweight concrete. Technical report, the instuto di scienza delle costruzioni, facolta di ingegneria, Palermo; Published by minestero della publica instuzione, Palermo, Italy; 1997. P. 3-22.

[5] Gunduz L, Ugur I. The effects of different fine and coarse pumice aggregate/cement ratios on the structural concrete properties without using any admixtures. Cem Concr Res 2005; 35: 1859-1864.

[6] Hanifi Binici., Effect of crushed ceramic and basaltic pumice as fine aggregates on concrete mortars properties, constructions and building materials; $21: 1191-1197$ (2007).

[7] Rosario Madrid, C. A. Nogueira and F. Margarido, Production and Characterisation of Amorphous Silica From Rice Husk Waste, $4^{\text {th }}$ International Conference on Engineering for Waste and Biomass Valorisation September 10-13, 2012 - Porto, Portugal.

[8] Tayfun Uygunoglu, Witold Brostow, Osman Gencel, Ilker Bekir Topcu, Bond Strength of Polymer Lightweight Aggregate Concrete. Polymer Composites-2013. DOI 10.1002/pc. 2131.

[9] Wasserman R, Bentur A, Effect of lightweight fly ash aggregate microstructure on the strength of concrete, Cement Concrete Research 1997; 27(4) : 525-537.

[10] Yang CC, Huang R. Approximate strength of lightweight aggregate using micromechanics method. Adv Cem Based Mater 1998; 7(3-4): 133-8.

[11] Zhang MH, Gjorv OE. Characteristics of lightweight aggregates for high-strength concrete, ACI Mater J, 1991 (March-April): 150-158. 